\title{
Challenges and Prospects of Smallholder Oil Palm Production in Awka Agricultural Zone of Anambra State, Nigeria
}

\author{
${ }^{1}$ Enwelu*, I. A., Nwanegbo*, O. A., Onoh Peter* and Ifejika ${ }^{\star * *}$ P. I. \\ Department of Agricultural Extension \\ University of Nigeria, Nsukka \\ Email: enwachonamin@yahoo.com \\ Mobile Phone: +2348035090033 \\ Department of Agricultural Extension \\ Federal University of Technology, Owerri \\ Email: peter_onoh@yahoo.com \\ National Institute for Freshwater Fisheries Research, \\ P.M.B. 6006, New Bussa, Niger State, Nigeria \\ Emails: ifejikaphilip@gmail.com \& ifejikaphilip@yahoo.com
}

\section{Abstract}

The study examined the challenges and prospects of smallholder oil palm production in Awka Agricultural Zone of Anambra State. Seventy two smallholder oil palm farmers were interviewed for the purpose of eliciting information. Smallholder oil palm farmers in Awka Agricultural Zone were educated (79.2\% Senior Secondary School Certificate and above) and fairly economically stable with $41.7 \%$ and $18.1 \%$ earning more than $\$ 40,000.00$ and between $\$ 30,001.00$ $\$ 40,000.00$ per month respectively from the oil palm enterprise. Oil palm production practices were characterized with the use of unimproved varieties/natural regeneration ( $M=0.97)$; use of baskets for seed germination $(M=0.69)$ and manual harvesting $(M=0.88)$. The challenges of smallholder oil palm production included: high cost of land $(M=2.79 ; S D=0.63)$; lack of access to credit $(M=2.75 ; S D=0.62)$; lack of improved planting materials- seeds/seedlings $(M=2.51$; $S D=0.73)$; lack of storage facilities $(M=2.50 ; S D=0.77)$ and lack of processing facilities ( $M=2.44 ; S D=0.84)$. In spite of these challenges, the perceived prospects of oil palm production in the zone were enormous, namely; as source of revenue for government and the citizens $(M=2.99$; $S D=0.59)$; could raise the standard of living of smallholder farmers $(M=2.97$; $S D=0.58)$; increase in oil palm output/yield $(M=2.93 ; \quad S D=0.83)$; increase in farmers' income $(M=89 ; S D=0.80)$ and improvement in food security $(M=2.88 ; S D=0.60)$. The study recommended among other things the provision of access to credit and loan facilities, improved varieties of planting materials, modern harvesting, processing and storage facilities.

Key words: Challenges, prospects, oil palm smallholder, Anambra State

\section{Introduction}

The oil palm has potential role to play in the drive for more sustainable farming systems. Some of the positive aspects of oil palm cultivation with regard to the environment are as follows:

- $\quad$ Although oil palm is most efficiently grown as a monoculture, pesticide use is seldom required provided proper ground conditions are maintained to supply the habitat necessary for the build-up of naturally occurring pest predators.

- $\quad$ As with other tree crops, the oil palm provides year-round ground cover which protects the soil from erosion.

- Well managed oil palms sequester more carbon (c) per unit area than tropical rainforest and oil palm estates are predicted to become an important part of carbon offset management. 
- $\quad$ About 25 percent of the harvested biomass may be returned to the field as nutrient rich mulch, providing opportunities for growers to recycle nutrient and biomass from more fertile to less fertile parts of the estate (Fairhust and Mutert 1999).

On the other hand, according to Sivasothy (2006), oil palm can be used in various other forms:

- $\quad$ The leaves are used in making brooms and as roofing materials (in the rural areas).

- $\quad$ The bark of the frond can be peeled and woven into baskets. The main trunk can be split like sawn timbers and used as part of building materials.

- $\quad$ Palm wine can be obtained from oil palm, red palm oil is readily obtainable from the fresh fruit bunches.

- When the fruit is processed the residue obtained can be used as fuel (for cooking and fertilizer to improve soil nutrient).

- $\quad$ Red palm oil is used in cooking, making soap, candle and margarine. Palm kernel oil can be extracted from the nut.

From a production level of $1.6 \%$ and a consumption level of $6 \%$ in 1976, global palm oil production and consumption has grown to $28 \%$ in 2009 to become the world's largest produced and consumed oil. Palm oil recorded its fastest increase in global production and consumption due to the significant contributions by Malaysia and Indonesia. Unfortunately, it is established fact that Malaysia collected palm nuts from Ufuma in Anambra State in the early 70 s (Olukayode 2012).

He further stressed that as early as 1900 , Nigeria was producing all palm oil sold in the world market and it was considered a dominant source of foreign exchange. In the 1950s and 1960s, Nigeria was a leader in the world palm oil market to which excess of Nigeria's palm oil was exported when the production of palm oil exceeded the domestic consumption. Up till the 1960s, Nigeria was the world's largest producer of palm oil accounting for $43 \%$ of global palm oil production. Over the past four decades, the gap between production and consumption has widened as consumption has grown more rapidly than production.

The fortunes of Nigeria's palm oil production, however, took a plunge as a result of the discovery of crude petroleum deposit in commercial quantity, over-reliance on traditional palm oil processing techniques, and the effects of Nigerian civil war between 1967-1970 which was greatly pronounced in Nigeria's oil palm belt (including Anambra State) (Olukayode,2012). He further stated that over-reliance on traditional production methods, excessive tapping of palm trees for palm wine and neglect prompted by much emphasis on petroleum at the expense of agriculture contributed to Nigeria's inability to meet up with the global rise in demand for palm oil.

In Anambra state, most of the oil palm enterprises are small to medium scale in size. More than $90 \%$ of the oil palm is accounted for by small scale farmers with less than two hectares under cropping and most of the oil palms are not derived from the cultivated oil palms but the grooves of the palms growing wild often in a state of semi-cultivation (Federal Ministry of Agriculture and Rural Development (FMARD), 2006).

Also, oil palm production in the state may have been largely affected by under investment in new technology, slow adoption of existing improved technology, limited land for oil palm cultivation and unavailability of skilled and unskilled labour. Again, there exist in the state, low production/output as well as low yielding varieties of palm seedlings planted at high maintenance cost (FMARD 2006). 
On the basis of the foregoing, the study was designed to: ascertain the socio-economic characteristics of small holder oil palm farmers in Awka Agricultural Zone; examine the existing small holder oil palm production practices in the study area; ascertain challenges of small holder oil palm farmers; and determine the prospects of the smallholder oil palm industry in the zone.

\section{Methodology}

The study was carried out in Awka agricultural zone. Awka is sited in a fertile tropical valley but most of the original rain forest has been lost due to clearing for farming and human settlement. The zone produces mainly crops and livestock. Some of the crops produced include oil palm, yam, coco yam, cassava, maize etc.

The population of the study constitutes all smallholder oil palm farmers. A multistage sampling technique was used in selecting respondents. In the first stage, three blocks were selected out of the five blocks in the study area using simple random selection technique. In the second stage, two cells were selected in each of the three blocks to give a total of six cells. In the third stage, four sub-cells were selected in each of the six cells to give twenty four (24) sub-cells. In stage four, from each of the sub-cell, three farmers were selected using simple random selection technique to give a total of seventy two (72) farmers for the study. Data for the study was collected using interview schedule. The instrument was divided into four sections based on the objectives of the study. The data collected were analysed using percentage and mean scores.

\section{Results and Discussion}

\section{Socio-economic characteristics of the respondents}

Data in Table 1 show that greater proportion (20.9\%) of the respondents were between 3640 years. The average age of the respondents was about 43 years. Majority (69.4\%) of the respondents was males and married. Only $1.4 \%$ had no formal education with majority $(52.8 \%)$ of the respondents having a farming experience of 15 years and above. Also, majority $(59.7 \%)$ took farming as their major occupation with greater proportion $(41.7 \%)$ making a monthly income of over $\$ 40,000.00$ from oil palm production.

The findings reveal that most of the farmers are in their middle and productive age and as such a bright prospect for the oil palm industry. The interest of youths in oil palm business is of particular importance in terms of employment which is one of the main focus of the present administration. The fact that majority of the respondents are married implies that the families may provide part of labour highly needed in oil palm production. The respondents are fairly educated and can adopt improved varieties of oil palm seedlings and other oil palm production technologies. According to Olukayode (2012), Major challenges facing the palm oil sector, affecting its competitiveness and potential for growth include the dominant presence of the wild grove of low yielding variety in the production system. 
Table 1: Percentage distribution of respondents according to socio-economic Characteristics

\begin{tabular}{|c|c|}
\hline Socio-economic characteristics & Percentage (\%) \\
\hline \multicolumn{2}{|l|}{ Age } \\
\hline Below 25 years & 7 \\
\hline $26-30$ & 5.6 \\
\hline $31-35$ & 9.8 \\
\hline $36-40$ & 20.9 \\
\hline $41-45$ & 11.2 \\
\hline $46-50$ & 15.4 \\
\hline $51-55$ & 12.6 \\
\hline $56-60$ & 11.2 \\
\hline $61-65$ & 2.8 \\
\hline $66-70$ & 4.2 \\
\hline \multicolumn{2}{|l|}{ Sex } \\
\hline Male & 69.4 \\
\hline Female & 30.6 \\
\hline \multicolumn{2}{|l|}{ Marital status } \\
\hline Single & 22.2 \\
\hline Married & 69.4 \\
\hline Divorced/separated & 1.4 \\
\hline Widow/Widower & 5.6 \\
\hline \multicolumn{2}{|l|}{ Educational qualification } \\
\hline No formal education & 1.4 \\
\hline Primary education & 18.1 \\
\hline Secondary education & 37.5 \\
\hline OND/NCE & 23.6 \\
\hline HND/First Degree & 18.1 \\
\hline \multicolumn{2}{|l|}{ Farming experience } \\
\hline $1-5$ years & 22.5 \\
\hline $6-10$ years & 15.5 \\
\hline 11.15 years & 8.5 \\
\hline Above 15 years & 53.5 \\
\hline \multicolumn{2}{|l|}{ Occupation } \\
\hline Civil Service & 23.6 \\
\hline Farming & 59.7 \\
\hline Trading & 5.6 \\
\hline Artisan & 5.6 \\
\hline \multicolumn{2}{|l|}{ Monthly income } \\
\hline$\leq 10,000$ & 1.4 \\
\hline $10,001-20,000$ & 5.6 \\
\hline $20,001-30,000$ & 13.9 \\
\hline $30,001-40,000$ & 18.1 \\
\hline$>40,000$ & 41.7 \\
\hline
\end{tabular}




\section{Smallholder oil palm production practices}

Results in Table 2 show that bush clearing $(\mathrm{M}=0.97 ; \mathrm{SD}=0.165)$, natural regeneration $(\mathrm{M}=0.97 ; \mathrm{SD}=0.298)$, manure application $(\mathrm{M}=0.97 ; \mathrm{SD}=0.165)$, traditional harvesting method ( $M=0.90 ; S D=0.298)$, use of machete $(M=0.86 ; S D=0.348)$ etc were the major production practices in use in Awka agricultural zone. The practices not in use included: use of dura $(\mathrm{M}=0.14 ; \mathrm{SD}=0.348)$ and tenera varieties $(\mathrm{M}=0.43 ; \mathrm{SD}=0.499)$, use of harvesting machines $(\mathrm{M}=0.15 ; \mathrm{SD}=0.362)$, wooden handled chisel $(\mathrm{M}=0.17 ; \mathrm{SD}=0.375)$ and sickle $(M=0.24 ; S D=0.484)$, use of seed germination tray $(M=0.44 ; S D=0.500)$ etc

Bush clearing is one the major preliminary practices required in oil palm production. It is a major challenge to smallholder farmers because of the capital intensive nature of the activity. The result also reveals that majority of the farmers still depend on natural regeneration to sustain their plantation in the wild grove. The use of improved tenera hybrid by the farmers in the zone is very poor and likely to adversely affect the productivity of oil palm. Researchers stressed that $80 \%$ of oil palm production in Nigeria comes from dispersed smallholders who harvest semi-wild plants and use manual processing techniques (Olagunju, 2008, Oil World Annual 2004). The use of traditional harvesting methods negatively affects smallholder farmers who already have over aged palms. The results of the standard deviation indicate that most of the respondents actually experience the situation under investigation. 
Table 2: Mean distribution of production practices in use

\begin{tabular}{|c|c|c|}
\hline Production practices & Mean & Standard deviation \\
\hline Bush clearing & $0.97^{*}$ & 0.165 \\
\hline Burning & 0.49 & 0.503 \\
\hline Tilling & 0.57 * & 0.500 \\
\hline Ridging & 0.22 & 0.419 \\
\hline \multicolumn{3}{|l|}{ Varieties used for planting } \\
\hline Dura & 0.14 & 0.348 \\
\hline Pisifera & 0.82 * & 0.387 \\
\hline Tenera & 0.43 & 0.499 \\
\hline Natural regeneration & 0.97 * & 0.298 \\
\hline \multicolumn{3}{|l|}{ Fermentation of the seeds } \\
\hline Soaking in water & 0.43 & 0.499 \\
\hline Burying & 0.50 * & 0.503 \\
\hline \multicolumn{3}{|l|}{ Heat treatment of the seeds } \\
\hline Exposure to sun & $0.75^{\star}$ & 0.436 \\
\hline Burying under layers of soil & 0.11 & 0.316 \\
\hline Tying in polythene bags & 0.44 & 0.500 \\
\hline \multicolumn{3}{|l|}{ Medium for seed germination } \\
\hline Top soil & $0.68^{*}$ & 0.470 \\
\hline $\begin{array}{l}\text { Conventional standard nursery mixture of top } \\
\text { soil, river sand and manure }\end{array}$ & $0.63^{*}$ & 0.488 \\
\hline Rice husk & 0.31 & 0.464 \\
\hline \multicolumn{3}{|l|}{ Germination containers using } \\
\hline Basket & $0.69^{*}$ & 0.464 \\
\hline Tray & 0.44 & 0.500 \\
\hline Poly bags & 0.56 * & 0.500 \\
\hline \multicolumn{3}{|l|}{ Enriching the soil by } \\
\hline Application of fertilizer & $0.57^{*}$ & 0.499 \\
\hline Application of manure & $0.97^{*}$ & 0.165 \\
\hline \multicolumn{3}{|l|}{ Harvesting technique } \\
\hline Traditional method & & 0.298 \\
\hline \multicolumn{3}{|l|}{ Equipment used for harvesting } \\
\hline Wooden handled chisel & 0.17 & 0.375 \\
\hline Axe & $0.69^{*}$ & 0.428 \\
\hline Matchete & 0.86 * & 0.348 \\
\hline Sickle & 0.24 & 0.484 \\
\hline${ }^{*}$ Cut off $=0.50$ & & \\
\hline
\end{tabular}

\section{Challenges of smallholder oil palm farmers}

Table 3 indicates that lack of land $(M=2.97)$, lack of access to credit and loans $(M=2.75)$, lack of improved planting materials $(M=2.51)$, Lack of storage facilities $(M=2.50)$, Lack of processing facilities $(M=2.44)$, High cost of fertilizer etc. were the major challenges of smallholder oil palm farmers. On the other hand, lack of market $(M=0.51)$ and lack of fertile soil $(M=1.03)$, were not seen as challenges facing smallholder oil palm farmers in the zone.

The major challenge facing oil palm farmers in embarking on oil palm production project is land. The existing land tenure system and the present land policy are not favourable to young farmers who may be interested in investing in oil palm production.

The high cost of land and lack of access to credit and loan may prevent young prospective farmers from venturing into oil palm business. According to Songa and Goad (2006), lack of 
access to capital (external source of credit) was a problem in smallholder oil palm production system. The challenge of processing facilities is major setback in oil palm industry. There are very inefficient processing technologies, extracting $25-50 \%$ of the oil content (i.e. this is equivalent to $50 \%$ of the oil is being thrown away) for half of all processed palm fruit (Olukayode, 2012). To compound the situation is the challenge of lack of improved planting Material. According to him, major challenges facing the palm oil sector, affecting its competitiveness and potential for growth include the dominant presence of the wild grove of low yielding variety

Table 3: Mean distribution of challenges of smallholder oil palm farmers

\begin{tabular}{lll}
\hline Challenges & Mean & $\begin{array}{l}\text { Standard } \\
\text { deviation }\end{array}$ \\
\hline High cost of land & 2.79 * & 0.627 \\
Lack of access to credit and loans & $2.75^{*}$ & 0.622 \\
Lack of fertile soil & 1.03 & 1.162 \\
Lack of improved planting materials seed/seedlings & 2.51 * & 0.731 \\
Lack of storage facilities & $2.50^{*}$ & 0.769 \\
Lack of processing facilities & $2.44^{*}$ & 0.837 \\
High cost of agro-chemicals & $2.50^{*}$ & 0.839 \\
High cost of fertilizer & $2.18^{*}$ & 0.998 \\
Incompatibility of modern technology to local conditions & $1.977^{*}$ & 0.731 \\
Lack of market & 0.51 & 0.787 \\
Low returns & 1.64 * & 0.827 \\
Infestation of pest and diseases & $1.99 *$ & 0.831 \\
Unavailability of seedlings & 1.99 * & 0.778 \\
\hline
\end{tabular}

${ }^{*}$ Cut off $=1.50$

\section{Perceived prospects of smallholder oil palm farmers}

Entries in Table 4 show the following respondents' perceived prospects of smallholder oil palm industry in Awka zone: increase in revenue of government $(M=2.99)$, improved standard of living of smallholder farmers $(M=2.97)$, increase in yield (output) $(M=2.93)$, increase in farmers' income $(M=2.89)$, improvement of food security $(M=2.88)$, increase in quality of produce $(\mathrm{M}=2.79)$, employment generation $(\mathrm{M}=2.76)$ and reclaiming of waste lands $(\mathrm{M}=2.76)$.

In spite of the numerous challenges facing oil palm farmers, the prospects or potentials of oil palm industry is great in Awka agricultural zone. The soil of the state is suitable for production of the crop and as such increased output is assured if the needed technology is applied. It has great potential in generating income and improved standard of living of smallholder farmers. Olagunju (2008) stated that efforts to raise agricultural production and farmers' standard of living require the introduction of improved farm equipments and technologies as well as increased availability and utilization of energy and power. The technologies/farm equipment should be appropriate with regard to maintenance cost, less technical expertite, affordability and production efficiency. 
Table 4: Mean distribution of perceived prospects of smallholder oil palm farmers.

\begin{tabular}{lll}
\hline Prospects & Mean & Standard deviation \\
\hline Increase in yield (output) & $2.93^{*}$ & 0.828 \\
Increase in quality of produce & $2.79^{*}$ & 0.604 \\
Increase in farmers' income & $2.89^{*}$ & 0.797 \\
Increase in standard of living of smallholder & & \\
farmers & $2.97^{*}$ & 0.580 \\
Increase in revenue of government & $2.99^{*}$ & 0.593 \\
Employment generation & $2.76^{*}$ & 0.741 \\
Reclaiming of waste lands & $2.76^{*}$ & 0.681 \\
Improvement of food security & $2.88^{*}$ & 0.604 \\
\hline
\end{tabular}

\section{${ }^{*}$ Cut off $=2.5$}

\section{Conclusion/Recommendation}

Oil palm industry remains the one of the most important economic sector in Nigeria. Presently, the production practices are bedevilled by traditional method and inefficient technologies. Smallholder farmers face such challenges as lack of land, lack of access to credit and loans, lack of improved planting materials, lack of storage facilities, lack of processing facilities and high cost of fertilizer etc. In spite of these challenges, there still exist such prospects as increase in revenue of government, improved standard of living of smallholder farmers, increase in output and increase in farmers' income.

The study recommended among other things the provision of access to credit and loan facilities, improved varieties of planting materials, modern harvesting, processing and storage facilities.

\section{References}

Fairhust and Mutert (1999). Better Crops International vol.13, No 1.

Federal Ministry of Agriculture and Rural Development (FMARD), 2006. National Programme for food security (NPFs). Expansion phase project 2006-2010.

Fedepalma, (2000). Oil Palm Plantation: Retrieved from http://www.fedepalma.ore/oilpalm.htm

Olagunju F.I. (2008) Economics of palm oil processing in southeastern Nigeria. International Journal of Agricultural Economics and Rural Development 1(2); 69-77.

Oil World Annual (2004) oil world, Ista Hamburg.

Olukayode Oyeleye (2012). Bridging supply-demand gap in palm oil business Downloaded on $20^{\text {th }}$ February, 2013 (http://www.worldstagegroup.com/worldstagenew/index.php?active=page\&pgcat=bizd ev)

Sivasothy K (2006). Continuous sterilization: The new paradigm for modernizing palm oil milling. J. Oil Palm Res., 144-152 